\title{
MJN EFFECTIVENESS OF GINGER KEPOK BANANA COOKIES CONSUMPTION TO DECREASE PREGNANT WOMEN EMESIS
}

\author{
Kusmiyati ${ }^{1 *}$, Ani Radiati², Sofia Februanti ${ }^{1}$ \\ 'Program Study D3 Nursing, Poltekkes Kemenkes Tasikmalaya, Indonesia \\ ${ }^{2}$ Department of Nutrition, Poltekkes Kemenkes Tasikmalaya, Indonesia
}

*Corresponding Author's Email: kusmiyatimunir@gmail.com

\begin{abstract}
Nausea or vomiting commonly called morning sickness is common in early pregnancy. But if not treated further, it will turn into hyperemesis gravidarum which can threaten the health of the mother and fetus. This study aims to determine the effect of consumption of kepok banana ginger biscuits on the risk of decreased emesis in pregnant women. The research design uses quasi experiment, with pretest and post-test design with two experiments. This research was conducted in the working area of the Kahuripan Tasikmalaya Community Health Center, Indonesia, among first trimester pregnant women with 8-16 weeks gestational age who experience nausea, vomiting, with physiological pregnancy. The sampling technique used purposive sampling technique, with a total sample of 30 people in the intervention group and 30 in the control group. Data analysis was done using univariate and bivariate. The results showed that after pregnant women consumed 6 pieces of biscuits for 4 days, consumption of kepok banana ginger biscuits could reduce the emesis of pregnant women. Pregnant women are expected to consume kepok banana ginger biscuits to reduce nausea and vomiting.
\end{abstract}

Keywords: Emesis, Pregnant Women, Banana Kepok Ginger Biscuits

\section{INTRODUCTION}

Pregnancy is a major event in a woman's life. Pregnancy is a physiological state, which produces several normal and expected changes in all normal maternal organ systems. Pregnancy can be different for each mother, and it can even be different for one pregnancy to the next for the same mother (Srivastava, Verma \& Prasad, 2019).

Pregnancy symptoms that affect a mother can be temporary. Nausea, vomiting in pregnancy is the most common complaint in early pregnancy and disturbs pregnant women. Combined HCG hormones and psychological factors are independently associated with nausea and vomiting during early pregnancy (Dekkers et al., 2019). Nausea and vomiting affects about $85 \%$ of pregnant women. The most severe form, hyperemesis gravidarum, affects up to $3 \%$ of women and can have significant physical and psychological sequelae (McParlin, O'Donnell \& Robson, 2016).

Management of nausea, vomiting in pregnancy can use various therapies such as anti-nausea, vomiting drugs (ondansetron), but it should be noted that drug administration is not teratogenic during fetal organogenesis (Taylor \& Ooi, 2018; Källén, 2019). Besides, some types of complementary medicine are generally consumed in our lives. Aromatherapy with lemon oil can show beneficial effects on nausea and vomiting among pregnant women (Fattah et al., 2019). According to the results of the review, most of the methods that are effective in reducing the incidence of vomiting in pregnancy, including ginger and P6 acupressure can be recommended (Ozgoli \& Naz, 2018). Many research results show that to eliminate nausea and vomiting in pregnant women in the first trimester, ginger and vitamin B6 are used for nausea (Sharifzadeh et al., 2018; Marx, Kiss \& Isenring, 2015). The results of the research of Kim, Lee, Jung (2018), ginger extract candy with Salicornia herbacea $L$. can reduce the nausea of vomiting in first-trimester pregnant women.

The most common way to avoid nausea first is to diet for example by eating very little but at regular interval and avoiding fatty foods that can stimulate nausea 
(Lindblad \& Koppula, 2016). Dietary recommendations during pregnancy are the same as recommendations for a normal healthy diet. Pregnant women must meet the nutrition of a balanced diet and need to be advised not to consume multivitamins and minerals in high doses. Kepok banana (Musa paradisiaca $L$ ) has a very good nutritional content, including providing fairly high energy compared to other fruits. Fresh kepok banana per 100 grams has an energy content of $109 \mathrm{kcal}$, protein 0.8 gram, 0.5 grams fat, 26.3-gram carbohydrate, along with food fiber, copper, and vitamin B1 (NilaiGizi.com, 2018).

Research show that addition of banana flour in the manufacture of ginger biscuits, is expected to add variety of flavors, giving a distinctive aroma and also being able to meet the nutritional needs of pregnant women from this product and making the resulting cookies as one type of functional food to help reduce nausea and vomiting in pregnant women. This also helps in the fulfillment of nutrition requirement for pregnant women. Previously, the determination of formulas and organoleptic tests had been carried out (Radiati \& Kusmiyati, 2018).

\section{METHODOLOGY}

The research design used was a Quasi Experiment with a two Group Pretest-Posttest Design approach with a control group. The study was conducted in the work area of the Kahuripan Community Health Centres Tasikmalaya, Indonesia. The sample selection uses a purposive sampling technique with a total of 30 first trimester pregnant women 8-16 weeks gestational age, who experience nausea, vomiting, physiological pregnancy. Data collection techniques were carried out after acquiring research permit and then looking for prospective respondents who met the criteria. Research study was explained, and informed consent was taken. After the respondents agreed to participate, the intervention group was given banana ginger biscuits and biscuits without ginger for the control group. Observation sheets was distributed along with checklist sheets, they were previously explained the procedure for filling the forms. The rules of consumption were explained, namely 3 biscuits at $07.00 \mathrm{WIB}$ and 3 biscuits at $19.00 \mathrm{WIB}$, observing adherence to consume biscuits without ginger and ginger biscuits in 4 days, every day during the observation period at $07.00 \mathrm{WIB}$ and 19.00 WIB. Researchers contacted the respondent to make sure the respondent had consumed biscuits, so that the checklist sheet was faultless. Data analysis was done using univariate and bivariate analysis .

\section{RESULTS}

Table 1: Distribution characteristic of Mother

\begin{tabular}{|c|c|c|c|c|}
\hline \multirow{2}{*}{ Age of Mother } & \multicolumn{4}{|c|}{ Group } \\
\cline { 2 - 5 } & \multicolumn{2}{|c|}{ Case } & \multicolumn{2}{c|}{ Control } \\
\cline { 2 - 5 } & $\mathrm{N}$ & $\%$ & $\mathrm{~N}$ & $\%$ \\
\hline$<20$ & 0 & 0 & 1 & 3.3 \\
$20-35$ & 26 & 86.7 & 26 & 86.7 \\
$36-40$ & 3 & 10.0 & 2 & 6.7 \\
$>40$ & 1 & 3.3 & 1 & 3.3 \\
\hline Total & 30 & 100 & 30 & 100 \\
\hline
\end{tabular}

From the data in table 1 it was evident that the most of the mothers were in the age group of age category 2035 years of the sample cases as many as 26 people $(86.75 \%)$ and the least age group that is $>40$ years as many as 1 person $(3.3 \%)$, whereas in the age control group the most samples were in the 20-35 year age category of 26 people $(86.75 \%)$ and the least age group of $>40$ years by 1 person $(3.3 \%)$.

Table 2: Distribution of Respondents by Characteristics of Emesis Gravidarum in Kahuripan Sub-District Tawang District Tasikmalaya City

\begin{tabular}{|c|c|c|c|c|}
\hline \multirow{3}{*}{ Characteristics } & \multicolumn{4}{|c|}{ Group } \\
\hline & \multicolumn{2}{|c|}{ Case } & \multicolumn{2}{|c|}{ Control } \\
\hline & $\mathbf{N}$ & $\%$ & $\mathbf{N}$ & $\%$ \\
\hline \multicolumn{5}{|c|}{ Stage } \\
\hline Primi gravidarum & 3 & 10 & 6 & 20 \\
\hline Multi Gravidarum & 27 & 90 & 24 & 80 \\
\hline Total & 30 & 100 & 30 & 100 \\
\hline \multicolumn{5}{|c|}{ Occurrence Time of Emesis } \\
\hline Morning & 23 & 76.7 & 24 & 80 \\
\hline Others & 7 & 23.3 & 6 & 20 \\
\hline Total & 30 & 100 & 30 & 100 \\
\hline \multicolumn{5}{|c|}{ Pregnancy Age } \\
\hline 8 Week & 16 & 53.3 & 8 & 26.7 \\
\hline 12 Week & 1 & 3.3 & 7 & 23.3 \\
\hline 13 Week & 2 & 6.6 & 1 & 3.3 \\
\hline 15 Week & 2 & 66 & 3 & 10.0 \\
\hline 16 Week & 9 & 30.0 & 11 & 36.7 \\
\hline Total & 30 & 100 & 30 & 100 \\
\hline
\end{tabular}

Based on the results of research in the working area of the Kahuripan subdistrict, Tasikmalaya City, Indonesia, respondents based on parity in the case group with Primi gravidarum by $10 \%$ and multigravida by $90 \%$ whereas in the control group with Primigravidarum as 
much as $20 \%$ and multigravida as much as $80 \%$. Based on gestational age in the most cases group at 8 weeks gestation as many as 16 people $(53.3 \%)$, while in the control group most at 16 weeks gestation were 11 people $(36.7 \%)$. Based on the time of most emesis events in the morning, in the case group of 23 people $(76.7 \%)$ and the control group of 24 people (80\%).

Table 3: Cross Table Pre-Post (Before and After Given Biscuits)

\begin{tabular}{|c|c|c|c|c|c|c|}
\hline \multicolumn{7}{|c|}{ Effect of Ginger Banana } \\
\hline \multirow{3}{*}{$\begin{array}{c}\text { Biscuits } \\
\text { Giving }\end{array}$} & \multicolumn{4}{|c|}{ Emesis Status } & \multirow{3}{*}{$P$} & \multirow{3}{*}{$95 \% \mathrm{CI}$} \\
\hline & \multicolumn{2}{|c|}{$\begin{array}{c}\text { Case / } \\
\text { Gravidarum }\end{array}$} & \multicolumn{2}{|c|}{$\begin{array}{l}\text { No Emesis } \\
\text { Gravidarum }\end{array}$} & & \\
\hline & $\mathrm{N}$ & $\%$ & $\mathrm{~N}$ & $\%$ & & \\
\hline $\begin{array}{c}\text { Cases / Ginger } \\
\text { Banana }\end{array}$ & 7 & 21.2 & 23 & 85.2 & 0.000 & 0.047 \\
\hline $\begin{array}{l}\text { Control / } \\
\text { Without } \\
\text { Ginger }\end{array}$ & 26 & 78.8 & 4 & 13.5 & & \\
\hline
\end{tabular}

In table 3 it can be explained that in the case group before being given banana ginger biscuits, the incidence of non-emesis gravidarum was $0 \%$ or all respondents experienced emesis gravidarum, and after being given ginger biscuits banana as much as $85.2 \%$ or 23 people did not experience emesis. In the control group before being given a biscuit without ginger, no morning sickness incidence is $0 \%$ or respondents experiencing morning sickness, and after being given a biscuit without ginger $78.8 \%$ still had morning sickness, and $13.5 \%$ did not experience morning sickness by the results of the analysis, it is known that the $p$-value of 0.000 with OR $95 \%$ CI 0.047 , so that "There is an influence of banana ginger biscuits on emesis gravidarum".

\section{DISCUSSION}

Respondents who were involved in this study were pregnant women aged 20-35 years, multigravida with emesis or nausea, vomiting often occurs in the morning. For most gestational age was 8 weeks of age. In the intervention group, it turned out that pregnant women who were still experiencing emesis $21.1 \%$ than the control group with $78.8 \%$. Statistically significantly different, with a p-value of 0.000 , so it can be concluded that there is an effect of banana ginger biscuits on emesis gravidarum.

Emesis gravidarum or nausea and vomiting in pregnant women is the most common symptom in the first trimester around 50\%-90\% (Kaya et al., 2016). This is due to the increase in free radicals of Nitric Oxide (NO) and the release of neurotransmitters (serotonin) which can stimulate the vomiting center in the central nervous system. Processed drinks or foods made from ginger that contain zingerone antioxidant compounds that function as the capture of free radicals of Nitric Oxide (NO), inhibit the visceral afferent nerve input by acting as a 5-HT3 receptor antagonist (Pratiwi, 2017). Other research also suggests that ginger can exert potentially beneficial effects on nausea and vomiting as antagonism of 5-HT3 receptors (Marx et al., 2015). Ginger herbal medicine (Zingiber officinale Roscoe) is effective for treating nausea, vomiting and stomach hypomotility. Cholinergic M3 and 5-HT3 and 5-HT4 receptor serotonergic are involved in this condition (Giacosa et al., 2015).

Ginger can prevent nausea and vomiting because ginger can be a barrier to serotonin, a chemical that can cause the stomach to contract, causing nausea (Putri et al., 2017). The results of this study are consistent with other studies which stated that ginger works effectively to treat the symptoms of nausea and vomiting that arise during pregnancy and even hyperemesis gravidarum, because ginger has the effect of relaxing and weakening the muscles in the digestive tract, thereby reducing nausea and vomiting in pregnant women. The use of various ginger products greatly helps pregnant women reduce nausea and vomiting that they complain of (Matthews et al., 2015).

One other non-pharmacological therapy that is recommended for treating emesis gravidarum is banana. The spread of bananas is almost everywhere in Indonesia and has many benefits. One of which is as an anti-emesis gravidarum. Bananas contain vitamin B6 which is a vitamin that dissolves in water. Vitamin B6 can help increase the development of central nervous system cells in the fetus. With the right amount of vitamin B6, it will reduce morning sickness. One type of banana that is recommended for emesis gravidarum is Kepok banana (Ratih, 2017).

\section{CONCLUSION}

The available evidence suggests that ginger is a harmless and effective treatment for nausea and vomiting of pregnancy. However, we should keep in mind ginger quantity needed to be effective and also ginger quality is important from the perspective of safety. 


\section{REFERENCES}

Dekkers, G.W.F., Broeren, M.A.C., Truijens, S.E.M., Kop, W.J. \& Pop, V.J.M. (2019). Hormonal and psychological factors in nausea and vomiting during pregnancy. Psychological Medicine, 30, pp 1-8.

Fattah, A., Hesarinejad, Z., Rajabi Gharaii, N. \& Nasibi, M. (2019). The Effect of Aromatherapy on Nausea and Vomiting during Pregnancy: A Systematic Review and Meta -Analysis. International Journal of Pediatrics, 7(3), pp 9061-9070.

Giacosa, A., Morazzoni, P., Bombardelli, E., Riva, A., Bianchi Porro, G. \& Rondanelli, M. (2015). Can nausea and vomiting be treated with ginger extract? European Review for Medical and Pharmacological Sciences, 19(7), pp 1291-1296.

Källén, B. (2019). Maternal Use of Drugs for Nausea and Vomiting in Pregnancy and Infant Congenital Malformations in Maternal Drug Use and Infant Congenital Malformations. $1^{\text {st }}$ edition. Switzerland: Springer.

Kaya, C., Gasimova, R., Ekin, M. \& Yasar, L. (2016). Hyperemesis Gravidarum: Current Approaches for the Diagnosis and Treatment. Journal of Pregnancy and Child Health, 3: 296. doi:10.4172/2376-127X.1000296.

Kim, D.S., Lee, H., Jung, E.K. \& Joo, N. (2018). Quality Characteristics of Ginger Extract Candy with Salicornia herbacea L. for Calming Effect on Morning Sickness. Journal of the Korean Dietetic Association, 24(1), pp $19-30$.

Lindblad, A.J. \& Koppula, S. (2016). Ginger for nausea and vomiting of pregnancy. Canadian Family Physician, 62(2), pp 145.

Marx, W., Kiss, N. \& Isenring, L. (2015). Is ginger beneficial for nausea and vomiting? An update of the literature. Current Opinion in Supportive and Palliative Care, 9(2), pp 189-195.

Matthews, A., Haas, D.M., O'Mathúna, D.P. \& Dowswell, T. (2015). Interventions for nausea and vomiting in early pregnancy. Cochrane Database of Systematic Reviews, 9, Art. No.: CD007575.

McParlin, C., O'Donnell, A. \& Robson, S.C. (2016). Treatments for Hyperemesis Gravidarum and Nausea and Vomiting in Pregnancy A Systematic Review. JAMA, 316(13), pp 1392-1401.

NilaiGizi.com (2018). Pisang kepok, segar. Retrieved from: https://nilaigizi.com/gizi/detailproduk/690/nilaikandungan-gizi-Pisang-kepok,-segar.

Ozgoli, G. \& Naz, M.S.G. (2018). Effects of Complementary Medicine on Nausea and Vomiting in Pregnancy: A Systematic Review. International Journal of Preventive Medicine, 9:75.

Pratiwi, A. (2017) Analisis Kandungan Zingeron Pada Formulasi Minuman Fungsional Berbahan Dasar Jahe Dan Kacang-Kacangan Sebagai Antiemetik Pada Ibu Hamil. Universitas Brawijaya, Indonesia.

Putri, A.D., Andiani, D., Haniarti \& Usman (2017). Efektifitas pemberian jahe hangat dalam mengurangi frekuensi mual muntah pada ibu hamil Trimester I in Prosiding Seminar Nasional IKAKESMADA "Peran Tenaga Kesehatan dalam Pelaksanaan SDGs". Yogyakarta: Fakultas Kesehatan Masyarakat UAD, pp 99-105.

Radiati, A. \& Kusmiyati (2018). Pengembangan Biskuit jahe dengan pisang kepok untuk memenuhi kebutuhan zat gizi dan menurunkan risiko emesis pada ibu hamil. Poltekkes Kemenkes Tasikmalaya, Indonesia.

Ratih, R.H. (2017). The Vitamin B6 Content of Kepok Banana: An Alternative to Overcome Nausea for Pregnant Women. Journal Kesehatan Komunitas, 3(5), pp 193-195. 
Sharifzadeh, F., Kashanian, M., Koohpayehzadeh, J., Rezaian, F., Sheikhansari, N. \& Eshraghi, N. (2018). A comparison between the effects of ginger, pyridoxine (vitamin B6) and placebo for the treatment of the first trimester nausea and vomiting of pregnancy (NVP). The Journal of Maternal-Fetal \& Neonatal Medicine, 31(19), pp 2509-2514.

Srivastava, P., Verma, A. \& Prasad, R. (2019). Nutritional status and dietary pattern during pregnancy. The Pharma Innovation Journal, 8(4), pp 1176-1181.

Taylor, D.L. \& Ooi, C. (2018). Ondansetron use in the first trimester and risk of fetal malformations. LGBTQIA, 20(4). 